\title{
Myocardial injury after endovascular revascularization in critical limb ischemia predicts 1-year mortality: a prospective observational cohort study
}

\author{
Wojciech Szczeklik ${ }^{1,2}$ (D) Marek Krzanowski ${ }^{2,3} \cdot$ Paweł Maga $^{2,3} \cdot$ Łukasz Partyka $^{2,3} \cdot$ Jolanta Kościelniak ${ }^{2,3}$.

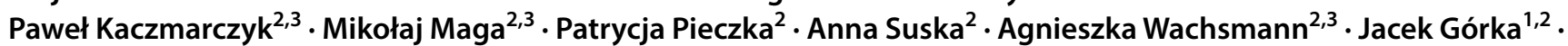 \\ Bruce Biccard ${ }^{4}$. P. J. Devereaux ${ }^{5}$
}

Received: 16 October 2017 / Accepted: 21 November 2017 / Published online: 24 November 2017

(c) The Author(s) 2017. This article is an open access publication

\begin{abstract}
Background Patients with critical limb ischemia (CLI) are at increased risk of cardiovascular complications and mortality. To determine (1) incidence of myocardial injury following endovascular revascularization, and (2) relationship between myocardial injury with 1-year mortality and major adverse cardiovascular events (MACE; i.e., composite of myocardial infarction, stroke, and death).

Methods and results Single-center, prospective cohort study of CLI patients $\geq 45$ years of age, who underwent endovascular revascularization with overnight hospitalization. High-sensitive troponins $\mathrm{T}$ (hsTnTs) were measured on admission, 3-6 $\mathrm{h}$ after endovascular revascularization and the subsequent morning. Myocardial injury after endovascular revascularization was defined as an hsTnT $\geq 14 \mathrm{ng} / \mathrm{L}$ with a relative increase $\geq 30 \%$ from the baseline value. We also evaluated other myocardial injury hsTnT thresholds (i.e., $\geq 30, \geq 40, \geq 60$, and $\geq 80 \mathrm{ng} / \mathrm{L}$ ). 239 consecutive patients (56\% male, mean age $71.5 \pm 10.1$ years) were included; one patient was lost to follow-up. At 1 year, there were 34 deaths (14.2\%), and 48 MACE (20.5\%). Myocardial injury with the hsTnT threshold of $14 \mathrm{ng} / \mathrm{L}$ and relative increase by $\geq 30 \%$ from the baseline level occurred in 61 patients (25.5\%). Myocardial injury was independently associated with 1-year mortality ([aHR], 2.44; 95\% CI 1.18-5.06, for hsTnT $\geq 14 \mathrm{ng} / \mathrm{L}$ to aHR, 3.34; 95\% CI 1.29-8.65 for hsTnT $\geq 80 \mathrm{ng} / \mathrm{L}$ ). Myocardial injury was also independently associated with 1-year MACE ([AOR] 2.89; 95\% CI 1.41-5.92 for hsTnT $\geq 14 \mathrm{ng} / \mathrm{L}$ to AOR, 6.69; 95\% CI 2.17-20.68 for hsTnT $\geq 80 \mathrm{ng} / \mathrm{L}$ ). $85.2 \%$ patients who had myocardial injury did not have ischemic clinical symptoms or electrocardiography changes. In sensitive analysis with exclusion of symptomatic patients that developed myocardial injury for the hsTnT $\geq 14 \mathrm{ng} / \mathrm{L}$ threshold, both the 1-year mortality (aHR: 2.19; CI 1.02-4.68; $p=0.04$ ), and 1-year MACE (OR 2.25; CI 1.06-4.77; $p=0.036$ ) remained significant.
\end{abstract}

Conclusions Myocardial injury is common following endovascular revascularization for CLI and associated with the risk of 1-year mortality and MACE.

Keywords Endovascular treatment $\cdot$ Peripheral artery disease $\cdot$ Critical limb ischemia $\cdot$ Myocardial injury $\cdot$ Major adverse cardiovascular events

Wojciech Szczeklik

wojciech.szczeklik@uj.edu.pl

1 Department of Intensive Care and Perioperative Medicine, Jagiellonian University Medical College, Krakow, Poland

2 Department of Medicine, Jagiellonian University Medical College, ul. Skawińska 8, 31-066 Krakow, Poland

3 Department of Angiology, Jagiellonian University Medical College, Krakow, Poland
4 Department of Anaesthesia and Perioperative Medicine, Faculty of Health Sciences, University of Cape Town, Cape Town, South Africa

5 Population Health Research Institute, McMaster University and Hamilton Health Sciences, Hamilton, ON, Canada 


\section{Introduction}

Globally $>200$ million individuals have lower extremity peripheral artery disease (PAD) [1-3]. The predominant etiology is atherosclerotic lesions that occlude the arterial lumen, compromising blood flow and resulting in ischemia. PAD shares several similarities in pathology and predisposing risk factors with coronary artery disease (CAD) and ischemic stroke [3, 4]. In all PAD patients, the risk of major adverse cardiovascular events (MACE) is three to sixfold higher than in the general population [5].

The most advanced stage of PAD is critical limb ischemia (CLI). This is a life-threatening condition [6], which affects approximately $1-2 \%$ of patients with PAD $[2,4]$. The reported incidence of CLI ranges from 500 to 1000 per million annually in the general population, and has increased by over $20 \%$ in the past decade [6].

The standard treatment for CLI is revascularization, which should be attempted in the majority of patients without delay [6-8]. The aim of this treatment is to obtain straight line, unimpeded arterial flow to the foot in at least one vessel. This can be performed either with an open surgical or percutaneous endovascular approach [9]. Even with adequate treatment, CLI carries a substantial burden of disability, suboptimal quality of life, and substantial health care and social costs $[6,10]$. Much of this is due to cardiovascular complications [11]. In the first year following the initial diagnosis of CLI mortality reaches $25 \%$ and surpasses $40 \%$ after 2 years [12-14]. In these cases, myocardial infarction is responsible for $40-60 \%$ of deaths and cerebral stroke for another $10-20 \%[5,12]$.

One of possible explanations for this high risk of MACE is that revascularization procedures (both surgical and endovascular) may result in myocardial injury at the time of intervention that may impact future prognosis. This hypothesis is based on the data from the noncardiac surgical setting, where perioperative cardiac ischemia is common, and has been shown in large studies that postsurgical troponin elevation increases the risk of short and long-term mortality and MACE [15-19]. A new termmyocardial injury after noncardiac surgery (MINS) has been introduced in perioperative medicine [20], which carries a broader spectrum of myocardial injury than that defined by the universal myocardial infarction definition [21], and is frequent in vascular surgery [22].

Although MINS occurs after surgical revascularization for CLI and impacts outcomes, a little is known about the incidence and prognosis of myocardial injury following endovascular revascularization for CLI. Similar to surgery, endovascular revascularization may provoke myocardial ischemia, possibly by procedure-associated pain, catecholamine release, anemia, coagulation abnormalities, hypotension, tachycardia, and hypoxia [23, 24].

We conducted an observational cohort study in patients who underwent percutaneous endovascular revascularization for CLI conducted under local anesthesia to determine the incidence of myocardial injury and the relationship between myocardial injury and mortality and MACE at 1 year.

\section{Methods}

\section{Study population}

Between the years 2013 and 2015, we conducted a singlecenter, prospective, observational cohort study of CLI patients undergoing endovascular revascularization in the Vascular Diseases Department of the Jagiellonian University Hospital, Krakow, Poland. Eligible patients were $\geq 45$ years of age and stayed at least overnight in hospital after the endovascular revascularization procedure. All patients fulfilled the definition of CLI according to current guidelines and were graded between 4 and 6 in the Rutherford classification $[6,10]$. Patients were excluded from the study if they declined consent or if the baseline high-sensitivie troponin $T$ (hsTnT) measurement or at least one post-procedural hsTnT measurement was not available.

The Jagiellonian University ethics committee approved the study. The protocol complied with the Helsinki Declaration, and all participants provided written informed consent before enrollment.

\section{Study procedures}

\section{Initial assessment}

Research personnel interviewed patients and reviewed their medical records to obtain information on patients' medical history. Before the endovascular revascularization all patients had an ECG performed and blood samples were taken at admission for C-reactive protein (CRP) and cardiac biomarkers [i.e., $\mathrm{N}$-terminal brain-type natriuretic peptide [NT-proBNP] and hsTnT (both Elecsys 2010 analyzer; Roche)]. Additional hsTnT measurements were performed 3-6 $\mathrm{h}$ after endovascular revascularization and the following morning. The $99 \%$ threshold for hsTnT in healthy population is $14 \mathrm{ng} / \mathrm{L}$ (coefficient of variations $<10 \%$ ) [25]. Preoperative estimated glomerular filtration rate (eGFR) was calculated using CKD-Epi equation and latest available preoperative serum creatinine value. Patients with an $\mathrm{hsTnT} \geq 14 \mathrm{ng} / \mathrm{L}$ after their procedure had an ECG performed and the presence of any clinical ischemic symptoms were recorded (e.g., chest pain, dyspnea). 


\section{Follow-up}

Research personnel followed patients throughout their hospitalization, and follow-up visits occurred in outpatient clinic at 1 month, 6 months and 1 year after endovascular revascularization. If the patient died or suffered MACE, the research team obtained the source documentation. Patients who either refused or were not able to come for the follow-up visits were contacted by phone, or their next-of-kin were contacted if study personnel could not reach the patient.

\section{Endovascular revascularization}

Endovascular revascularization was performed under local anesthesia. Once vascular access was established, the obstructive lesions were crossed by means of various catheters and guidewires. Next, the lumen was dilated, and either isolated (in 74 patients, $31 \%$ ) percutaneous transluminal angioplasty (PTA) or PTA with subsequent bare metal stent implantation (in 165 patients, 69\%) was performed. No drug-coated balloons were used in this study. All intravascular instrumentations were performed under angiographic guidance. At the end of the procedure, the vascular sheath was removed and the puncture site was sealed by manual compression or using closure devices.

\section{Study outcome measurements}

We defined myocardial injury following endovascular treatment as:

1) Post-procedural hsTnT $\geq 14 \mathrm{ng} / \mathrm{L}$

with

2) $\geq 30 \%$ relative increase from the baseline hsTnT measurement.

We also assessed other pre-specified myocardial injury thresholds: $\operatorname{hsTnT} \geq 30 ; \geq 40 ; \geq 60$; and $\geq 80 \mathrm{ng} / \mathrm{L}$ with the same obligatory relative increase of at least $30 \%$ from the baseline hsTnT level.

As there were no existing definitions of post-procedural myocardial injury at the time of the study commencement, the chosen obligatory relative increase of $30 \%$ in the hsTnT was based on previous studies that evaluated the delta changes in high-sensitive troponins levels, and suggested improved specificity for myocardial ischemia for this particular threshold [26].

The primary outcome was 1-year mortality, defined as death from any cause. The secondary outcome was major adverse cardiovascular event (MACE) that was defined as a composite of myocardial infarction, stroke and death (by any cause). If two events occurred in one patient (e.g., myocardial infarction followed by death) the patient was counted as having a single MACE. All potential MACE events were adjudicated independently by two physicians (internist and cardiologist).

\section{Statistical analyses}

Categorical variables are presented as counts (percentages), whereas continuous variables are reported as medians (25-75 quartile range) unless otherwise specified.

Categorical variables were compared between the groups who did and did not have myocardial injury by the chisquare or the Fisher's exact tests, and continuous variables were compared using the Student's $t$ test or the Mann-Whitney $U$ test as appropriate.

We undertook multivariable regression analyses and assessed the relationship between different thresholds of myocardial injury that occurred after revascularization with the outcomes, specifically the Cox proportional hazard regression for evaluation of the mortality and logistic regression analysis for MACE. The independent variables included in the models by forced simultaneous entry were sex, Rutherford grade, CAD, history of MI, diabetes mellitus, and preoperative levels of eGFR, NT-proBNP, and hsTnT.

We reported results as hazard ratios (HR); for Cox analyses and odds ratios (OR) for logistic regression, with the corresponding $95 \%$ confidence intervals and associated $p$ values. As a measurement of discrimination, we assessed the C-index for Cox analyses and area under the curve (AUC) for logistic regression analyses. For all tests, we used a twosided alpha $<0.05$ level of significance. All statistical analyses were performed using R software, version 3.3.2 (Vienna, Austria).

\section{Results}

\section{Patients and preoperative cardiac biomarkers}

Two hundred and thirty-nine consecutive patients were included; all patients were Caucasian, $56 \%$ were male, and the mean age was $71.5 \pm 10.1$ years. Almost $80 \%$ of patients had a Rutherford grade $\geq 5$ before their procedure, and most had multiple risk factors for cardiovascular diseases (e.g., $48 \%$ had known coronary artery disease and $20 \%$ congestive heart failure). Only one patient was lost to followup at 1-year. Figure 1 presents the study flow chart, and Table 1 reports the clinical and laboratory characteristics of included patients. During the 1-year follow-up period, MACE occurred in 48 patients (20.5\%) and 34 patients died (14.2\%). Outcomes up to 1-year are presented in Table 2. 
Fig. 1 Study flow chart



In 232 patients (97.1\%), hsTnT in all three points of measurement were available for the analysis (seven patients did not have hsTnT measured on the morning following endovascular revascularization). Median baseline hsTnT level was 18 (12-29) ng/L and 151 patients (62.1\%) had an hsTnT above the threshold level of $14 \mathrm{ng} / \mathrm{L}$. Median baseline NT-proBNP was 558 (195-1565) pg/mL (Table 2), and in 78 patients $(32 \%)$ the level of NT-proBNP was above the age-adjusted reference value [27].

\section{Myocardial injury after endovascular revascularization}

Median hsTnT was 18 (12-31.5) after 3-6 h from treatment and 21 (13-41) on the following morning. Myocardial injury based on the hsTnT threshold $\geq 14 \mathrm{ng} / \mathrm{L}$ and relative troponin increase of at least $30 \%$ occurred in 61 patients (25.5\%). Patients with myocardial injury ( $\geq 14 \mathrm{ng} / \mathrm{L})$ when compared to those without myocardial injury, were older, more frequently had congestive heart failure, beta-blocker usage, and higher baseline levels of white blood cells, CRP, baseline hsTnT and NT-proBNP and lower baseline levels of eGFR and hemoglobin. The comparison of patients' characteristics, treatments and laboratory findings between those that suffered myocardial injury $(\geq 14 \mathrm{ng} / \mathrm{L})$ and that did not is presented in Table 1.

In the myocardial injury ( $\geq 14 \mathrm{ng} / \mathrm{L})$ group, the peak (maximum) hsTnT was found in $16.3 \%$ of patients $6-12 \mathrm{~h}$ after the revascularization, and in the majority $(83.7 \%)$ by the next morning. Only six patients (9.8\%) with 
Table 1 Baseline characteristics

All patients $(n=239) \quad$ Patients without myocardial Patients with myocardial $\quad p$ value injury $(n=178) \quad$ injury $(n=61)$

\begin{tabular}{|c|c|c|c|c|}
\hline Age (years) $($ mean $\pm S D)$ & $71.5 \pm 10.1$ & $70.5 \pm 10.2$ & $74.4 \pm 9.4$ & 0.007 \\
\hline Age $>75$ years $n(\%)$ & $97(40.6 \%)$ & $62(34.8 \%)$ & $35(57.3 \%)$ & 0.003 \\
\hline Male $n(\%)$ & $134(56.1 \%)$ & $106(59.6 \%)$ & $28(45.9 \%)$ & 0.07 \\
\hline $\mathrm{BMI} \mathrm{kg} / \mathrm{m}^{2}($ mean $\pm \mathrm{SD})$ & $26.8 \pm 4.7$ & $26.8 \pm 4.6$ & $27.1 \pm 5.3$ & 0.809 \\
\hline \multicolumn{5}{|l|}{ Past medical history } \\
\hline Hypertension $n(\%)$ & $183(76.6 \%)$ & $133(74.7 \%)$ & $50(82 \%)$ & 0.295 \\
\hline Diabetes mellitus $n(\%)$ & $138(57.7 \%)$ & $100(56.2 \%)$ & $38(62.3 \%)$ & 0.454 \\
\hline Insulin treatment & $108(45.2 \%)$ & $78(43.8 \%)$ & $30(49.2 \%)$ & 0.551 \\
\hline $\mathrm{CAD} n(\%)$ & $115(48.1 \%)$ & $81(45.5 \%)$ & $34(55.7)$ & 0.184 \\
\hline Myocardial infarction $n(\%)$ & $59(24.7 \%)$ & $41(23.0 \%)$ & $18(29.5 \%)$ & 0.308 \\
\hline TIA/stroke $n(\%)$ & $44(18.4 \%)$ & $32(18.0 \%)$ & $12(20 \%)$ & 0.848 \\
\hline Chronic heart failure $n(\%)$ & $48(20.1 \%)$ & $28(15.7 \%)$ & $20(32.8 \%)$ & 0.006 \\
\hline Dialysis $n(\%)$ & $12(5.0 \%)$ & $8(4.5 \%)$ & $4(6.6 \%)$ & 0.508 \\
\hline Prior smoker $n(\%)$ & $170(71.1 \%)$ & $126(70.8 \%)$ & $44(72.1 \%)$ & 0.872 \\
\hline Current smoker $n(\%)$ & $30(12.6 \%)$ & $25(14.0 \%)$ & $5(8.2 \%)$ & 0.271 \\
\hline Rutherford $4 n(\%)$ & $49(20.5 \%)$ & $40(22.5 \%)$ & $9(14.8 \%)$ & 0.2698 \\
\hline Rutherford $5 n(\%)$ & $150(62.8 \%)$ & $112(62.9 \%)$ & $38(62.3 \%)$ & 1 \\
\hline Rutherford $6 n(\%)$ & $40(16.7 \%)$ & $26(14.6 \%)$ & $14(23 \%)$ & 0.163 \\
\hline \multicolumn{5}{|l|}{ Treatment } \\
\hline ASA & $234(97.9 \%)$ & $174(97.8 \%)$ & $60(98.4 \%)$ & 1 \\
\hline Clopidogrel & $227(95.0 \%)$ & $171(96.1 \%)$ & $56(91.8 \%)$ & 0.1895 \\
\hline Statin & $208(87.0 \%)$ & $160(89.9 \%)$ & $48(78.7 \%)$ & 0.044 \\
\hline B-blocker & $141(59.0 \%)$ & $95(53.4 \%)$ & $46(75.4 \%)$ & 0.003 \\
\hline ACE inhibitor & $144(60.3 \%)$ & $104(58.4 \%)$ & $40(65.6 \%)$ & 0.365 \\
\hline Heparin & $165(69.0 \%)$ & $118(66.3 \%)$ & $47(77 \%)$ & 0.149 \\
\hline Oral diabetes drugs & $55(23.0 \%)$ & $42(23.6 \%)$ & $13(21.3 \%)$ & 0.86 \\
\hline \multicolumn{5}{|l|}{ Laboratory parameters } \\
\hline $\mathrm{Hb} \mathrm{g} / \mathrm{dL}$ & $12.4(10.9-13.5)$ & $12.6(11.3-13.6)$ & $11.4(10.6-12.4)$ & 0.001 \\
\hline WBC count $\times 10^{3}$ cells $/ \mu / \mathrm{L}$ & $8.2(6.9-10.8)$ & $8.0(6.74-10.8)$ & $8.7(7.5-10.9)$ & 0.04 \\
\hline Platelet count $\times 10^{3}$ cells $/ \mu / \mathrm{L}$ & $233.5(190-311)$ & $230(190-307)$ & $255(194-319)$ & 0.622 \\
\hline CRP mg/L & $7.4(2.1-41.2)$ & $6.1(1.8-28.8)$ & $15.5(2.8-61.2)$ & 0.019 \\
\hline $\mathrm{CRP}>5 \mathrm{mg} / \mathrm{L} n(\%)$ & $144(60.3 \%)$ & $100(56.2 \%)$ & $44(72.1 \%)$ & 0.034 \\
\hline Creatinine $\mu \mathrm{mol} / \mathrm{L}$ & $83(67-102)$ & $81(65.5-99)$ & $87(68.8-110)$ & 0.22 \\
\hline eGFR & $74(56-96)$ & $78(57.3-98.8)$ & $65.5(50.3-87.8)$ & 0.031 \\
\hline Preoperative hsTnT ng/L & $18(12-29)$ & $17(11-27)$ & $22(14-35.5)$ & 0.017 \\
\hline NT-proBNP pg/ml median (Q1-Q3) & $558(195-1565)$ & $459(159-1365)$ & $1061(471-2490)$ & $<0.001$ \\
\hline
\end{tabular}

Continuous variables expressed as medians with 25-75 quartile range unless otherwise specified

$A C E$ angiotensin converting enzyme, $A S A$ acetylsalicylic acid, $B M I$ body mass index, $C A D$ coronary artery disease, $C R P$ C-reactive protein, GFR glomerular filtration rate, $H g B$ hemoglobin, $h s T n T$ high-sensitive troponin T, $N T$-proBNP N-terminal brain natriuretic peptide, $S D$ standard deviation, TIA transient ischemic attack, WBC white blood cells

myocardial injury ( $\geq 14 \mathrm{ng} / \mathrm{L})$ had ischemic symptoms (e.g., chest discomfort was present in three) and presumed new ECG ischemic changes. Three additional patients had new ECG ischemic finding without clinical symptoms. In total, nine patients $(14.8 \%)$ in the myocardial injury group presented with any ischemic symptoms (clinical symptoms and/or ECG changes).

\section{Myocardial injury and 1-year outcomes}

Patients who developed myocardial injury were more likely to die or suffer MACE within the 1-year follow-up after revascularization compared to the patients who did not have myocardial injury. 17/34 (50\%) of patients that died in the first year had myocardial injury ( $\geq 14 \mathrm{ng} / \mathrm{L}$ ). The outcomes 
Table 2 Outcomes in studied group

\begin{tabular}{|c|c|c|c|c|}
\hline & All patients $(n=239)$ & $\begin{array}{l}\text { Patients without myocardial } \\
\text { injury }(n=178)\end{array}$ & $\begin{array}{l}\text { Patients with myocardial } \\
\text { injury }(n=61)\end{array}$ & $p$ value \\
\hline Death (up to 1 year) $n \%$ & $34(14.2 \%)$ & $19(10.7 \%)$ & $15(24.6 \%)$ & 0.011 \\
\hline MI (up to 1 year) $n \%$ & $16(6.7 \%)$ & $7(3.9 \%)$ & $9(14.8 \%)$ & 0.007 \\
\hline Stroke (up to 1 year) $n \%$ & $9(3.8 \%)$ & $6(3.3 \%)$ & $3(4.9 \%)$ & 0.697 \\
\hline Composite end point (up to 1 year) $n \%$ & $48(20.1 \%)$ & $27(15.2 \%)$ & $21(34.4 \%)$ & 0.003 \\
\hline Amputation below knee (up to 1 year) $n \%$ & $8(3.3 \%)$ & $6(3.4 \%)$ & $2(3.2 \%)$ & 1 \\
\hline Amputation above knee (up to 1 year) $n \%$ & $23(9.6 \%)$ & $18(10.1 \%)$ & $5(8.2 \%)$ & 0.804 \\
\hline Re-intervention (up to 1 year) $n \%$ & $106(44.3 \%)$ & $83(46.6 \%)$ & $23(37.7 \%)$ & 0.237 \\
\hline
\end{tabular}

Continuous variables expressed as medians with 25-75 quartile range unless otherwise specified

$M I$ myocardial infarction

in unadjusted analysis for both 1-year mortality and MACE for different hsTnT thresholds for myocardial injury are presented in Table 3.

In the multivariable analysis, myocardial injury was found to be an independent predictor of both 1-year mortality and MACE. Adjusted hazard ratio for the association of myocardial injury after EVT with 1-year mortality varied from aHR: 2.44 (95\% CI 1.18-5.01) for hsTnT $\geq 14 \mathrm{ng} / \mathrm{L}$ to aHR: 3.34 (95\% CI 1.29-8.65) for myocardial injury after $\mathrm{EVT} \geq 80 \mathrm{ng} / \mathrm{L}$. Similar results were found for 1-year MACE with adjusted OR ranging from OR 2.89 (95\% CI 1.41-5.92) to OR 6.69 (95\% CI 2.17-20.68). Table 4 reports the 1-year mortality and MACE multivariable risk prediction models that included myocardial injury ( $\geq 14 \mathrm{ng} / \mathrm{L})$. Table 5 reports the comparison of different myocardial injury thresholds on the risk of 1-year mortality and MACE.

In sensitive analysis with exclusion of symptomatic patients that developed myocardial injury for the hsTnT $\geq 14 \mathrm{ng} / \mathrm{L}$ threshold (i.e., suffered MI), both the 1-year mortality (aHR: 2.19; CI 1.02-4.68; $p=0.04$ ), and 1-year MACE (OR 2.25; CI 1.06-4.77; $p=0.036$ ) remained significant.

\section{Discussion}

Given the burden of cardiovascular complications following revascularization for CLI, there is a need to understand potential precipitants of these adverse outcomes. We evaluated the influence of myocardial injury after endovascular treatment in CLI patients on 1-year mortality and MACE. The findings show that (1) preoperative cardiac biomarkers (hsTnT and NT-proBNP) are frequently elevated in CLI patients, (2) almost $25 \%$ of CLI patients experience myocardial injury after endovascular treatment, and (3) myocardial injury is independently associated with 1-year mortality and MACE.

Table 3 Univariate comparison of patients that suffered myocardial injury (with different hsTnT thresholds) and those that did not in terms of 1-year outcomes

\begin{tabular}{|c|c|c|c|c|c|c|c|c|}
\hline $\begin{array}{l}\text { Myocardial injury } \\
\text { TnT threshold } \\
\text { (ng/L) }\end{array}$ & $\begin{array}{l}\text { Presence of } \\
\text { myocardial } \\
\text { injury* }\end{array}$ & ALL $n=239$ & Death at 1-year & $\begin{array}{l}\text { OR }(95 \% \mathrm{CI}) \text { unad- } \\
\text { justed }\end{array}$ & $p$ value & MACE & $\begin{array}{l}\text { OR }(95 \% \mathrm{CI}) \text { unad- } \\
\text { justed }\end{array}$ & $p$ value \\
\hline \multirow[t]{2}{*}{14} & No & $178(74.5 \%)$ & $19(10.7 \%)$ & Reference & & $27(15.1 \%)$ & Reference & \\
\hline & Yes & $61(25.5 \%)$ & $15(24.6 \%)$ & $2.73(1.3-5.8)$ & 0.011 & $21(34.4 \%)$ & $2.94(1.50-5.73)$ & 0.003 \\
\hline \multirow[t]{2}{*}{30} & No & $197(82.4 \%)$ & $23(11.7 \%)$ & Reference & & $33(16.8 \%)$ & Reference & \\
\hline & Yes & $42(17.6 \%)$ & $11(26.2 \%)$ & $2.68(1.19-6.06)$ & 0.026 & $15(35.7 \%)$ & $2.76(1.33-5.75)$ & 0.01 \\
\hline \multirow[t]{2}{*}{40} & No & $204(85.4 \%)$ & $23(11.3 \%)$ & Reference & & $34(16.7 \%)$ & Reference & \\
\hline & Yes & $35(14.6 \%)$ & $11(31.43 \%)$ & $3.61(1.56-8.32)$ & 0.004 & $14(40 \%)$ & $3.33(1.54-7.20)$ & 0.003 \\
\hline \multirow[t]{2}{*}{60} & No & $216(90.4 \%)$ & $25(11.6 \%)$ & Reference & & $37(17.1 \%)$ & Reference & \\
\hline & Yes & $23(9.6 \%)$ & $9(39.1 \%)$ & $4.91(1.93-12.5)$ & 0.0016 & $11(47.8 \%)$ & $4.43(1.82-10.8)$ & 0.002 \\
\hline \multirow[t]{2}{*}{80} & No & $222(92.9 \%)$ & $27(12.2 \%)$ & Reference & & $38(17.1 \%)$ & Reference & \\
\hline & Yes & $17(7.1 \%)$ & $7(41.2 \%)$ & $5.06(1.78-14.4)$ & 0.004 & $10(58.8 \%)$ & $6.92(2.48-19.3)$ & $<0.001$ \\
\hline
\end{tabular}

*Myocardial injury for different post-procedural hsTnT thresholds with obligatory relative increase $\geq 30 \%$ from the baseline hsTnT measurement $C I$ confidence interval, MACE major adverse cardiovascular events, $O R$ odds ratio 
Table 4 Multivariable risk prediction model of 1-year mortality and MACE in CLI patients including myocardial injury after endovascular revascularization $(\geq 14 \mathrm{ng} / \mathrm{L}$ and $\geq 30 \%$ relative increase in hsTnT) and baseline cardiac biomarkers (hsTnT and NT-pro-BNP)

\begin{tabular}{|c|c|c|c|c|}
\hline & \multicolumn{2}{|l|}{ 1-year mortality } & \multicolumn{2}{|l|}{ 1-year MACE } \\
\hline & Adjusted hazard ratio $(95 \% \mathrm{CI})$ & $p$ value & Adjusted OR (95\% CI) & $p$ value \\
\hline Age & $0.99(0.95-1.033)$ & 0.653 & $0.99(0.96-1.03)$ & 0.715 \\
\hline \multicolumn{5}{|l|}{ Sex } \\
\hline Female & Reference & & Reference & \\
\hline Male & $0.71(0.31-1.64)$ & 0.426 & $0.84(0.39-1.82)$ & 0.658 \\
\hline \multicolumn{5}{|l|}{ Rutherford } \\
\hline 4 & Reference & & Reference & \\
\hline 5 & $1.52(0.50-4.59)$ & 0.461 & $1.259(0.49-3.26)$ & 0.634 \\
\hline 6 & $1.037(0.26-4.17)$ & 0.959 & $0.888(0.25-3.10)$ & 0.853 \\
\hline CAD & $1.64(0.66-4.09)$ & 0.288 & $1.37(0.56-3.35)$ & 0.492 \\
\hline History of MI & $0.87(0.33-2.269)$ & 0.768 & $1.19(0.47-3.04)$ & 0.714 \\
\hline $\mathrm{DM}$ & $0.89(0.41-1.93)$ & 0.773 & $1.19(0.57-2.48)$ & 0.639 \\
\hline CRP & $1.005(0.999-1.011)$ & 0.087 & $1.004(0.997-1.01)$ & 0.296 \\
\hline eGFR & $1.002(0.991-1.014)$ & 0.719 & $0.9997(0.9882-1.011)$ & 0.956 \\
\hline NT-proBNP & $1.00004(0.999-1.00009)$ & 0.149 & $1.00005(0.99998-1.00012)$ & 0.152 \\
\hline TnT0 & $1.002(0.994-1.01)$ & 0.649 & $0.999(0.987-1.011)$ & 0.868 \\
\hline $\begin{array}{l}\text { Myocardial injury: } \mathrm{hsTnT} \geq 14 \mathrm{ng} / \mathrm{L} \text { with } \\
\geq 30 \% \text { relative hsTnT increase }\end{array}$ & $2.44(1.18-5.06)$ & 0.016 & $2.89(1.41-5.92)$ & 0.004 \\
\hline
\end{tabular}

CRP, eGFR, TnT and NT-proBNP expressed in the model as continuous variables. Cox proportional hazard analysis for the 1-year mortality model $[\mathrm{C}$-index $=0.677(\mathrm{SE}=0.051)]$ with the corresponding adjusted hazard radio (aHR) and 95\% confidence interval (CI); multivariable logistic regression for 1-year MACE model [AUC $=0.65$ ] with the corresponding adjusted odds ratio and $95 \% \mathrm{CI}$

$C A D$ coronary artery disease, $C I$ confidence interval, $C R P$ C-reactive protein, $D M$ diabetes mellitus, $e G F R$ estimated glomerular filtration rate, $M A C E$ major adverse cardiovascular events, $M I$ myocardial infarction, $N T$-pro-BNP N-terminal brain natriuretic peptide, $T n T$ troponin $\mathrm{T}$

Table 5 Summary of multivariable results for different hsTnT myocardial injury thresholds and risk prediction of 1-year mortality and MACE

\begin{tabular}{|c|c|c|c|c|c|c|}
\hline \multirow{2}{*}{$\begin{array}{l}\text { Myocardial injury } \\
\text { TnT threshold* } \\
\text { (ng/L) }\end{array}$} & \multicolumn{3}{|l|}{ 1-year mortality } & \multicolumn{3}{|l|}{ 1-year MACE } \\
\hline & $\begin{array}{l}\text { Adjusted hazard } \\
\text { ratio }(95 \% \mathrm{CI})\end{array}$ & $p$ value & C-index & Adjusted OR (95\% CI) & $p$ value & AUC \\
\hline$\geq 14$ & $2.44(1.18-5.06)$ & 0.016 & 0.7 & $2.89(1.41-5.92)$ & 0.004 & 0.697 \\
\hline$\geq 30$ & $2.37(1.09-5.17)$ & 0.03 & 0.694 & $2.67(1.20-5.90)$ & 0.016 & 0.683 \\
\hline$\geq 40$ & $2.97(1.35-6.55)$ & 0.007 & 0.705 & $3.09(1.33-7.14)$ & 0.008 & 0.684 \\
\hline$\geq 60$ & $3.49(1.49-8.14)$ & 0.004 & 0.698 & $3.98(1.50-10.56)$ & 0.005 & 0.689 \\
\hline$\geq 80$ & $3.34(1.29-8.65)$ & 0.013 & 0.694 & $6.692(2.17-20.68)$ & 0.001 & 0.7 \\
\hline
\end{tabular}

*Myocardial injury for different post-procedural hsTnT thresholds with obligatory relative increase $\geq 30 \%$ from the baseline hsTnT measurement

$A U C$ area under the curve, $C I$ confidence interval, MACE major adverse cardiovascular events, $O R$ odds ratio
CAD is known to be present in 50-60\% of patients with CLI $[11,28]$ and is included in all of the risk stratification tools as a predictor of mortality. In a recent study by Chen and colleagues, the presence of CAD in CLI patients undergoing diagnostic angiography or endovascular treatment was associated with higher rate of 5-year mortality and major cardiovascular complications [29].

However, the presence of CAD may be underestimated in patients with CLI, who often suffer from diabetes and immobilization and do not present with typical (angina) chest pain. A large trial that evaluated coronary angiograms before vascular surgery in almost 300 patients with CLI found that only $8 \%$ had coronary arteries without atherosclerosis [30].

The recent introduction of the hsTnT assay enables the detection of limited myocardial injury even without tissue necrosis, and together with BNP evaluation may help in diagnosing cardiac diseases. Both troponins and BNP have been broadly studied in several medical conditions and their elevation have been associated with the presence 
of coronary artery disease, congestive heart failure and overall poor prognosis [31-34].

Pohlhammer and colleagues demonstrated that hsTnT is elevated in males with PAD when compared to diabetesmatched controls, and that hsTnT elevation correlated with the presence of cardiovascular diseases [35]. In another study in CLI patients, elevated TnI was associated with increased mortality over a median of 8 months (HR 3.1; 95\% CI 1.6-5.6) [36]. Both hsTnT [37] and BNP [38] among PAD patients were reported to be the highest in CLI patients.

In our study, we found that $62.1 \%$ of patients had preprocedural hsTnT values above the $99 \%$ percentile of a normal reference level and $32 \%$ of patients had ageadjusted elevated NT-proBNP. According to past medical histories, the majority of patients had several cardiovascular comorbidities (e.g., hypertension, diabetes), with known coronary artery disease being present in $48 \%$ and known congestive heart failure in $20 \%$. Considering the results of studied biomarkers cardiac disease may be underestimated in CLI patients.

Further, preoperative elevated cardiac biomarkers in CLI patients may reflect cardiac comorbidities (e.g., coronary artery disease, congestive heart failure and other cardiac conditions present in the clinical model), yet they may not be independently associated with post-procedural outcome (Table 4). Indeed, our data suggests that the only determinant of subsequent prognosis is dependent on monitoring the perioperative troponin response indicating myocardial injury.

The current study demonstrated a high prevalence of myocardial injury following revascularization. In the lowest evaluated threshold (hsTnT $\geq 14 \mathrm{ng} / \mathrm{L}$; with at least $30 \%$ relative increase from the baseline level), myocardial injury was found in $25.5 \%$ of patients. Only a minority of patients (14.8\%), who suffered myocardial injury after endovascular revascularization experienced clinical symptoms or had ECG findings indicative of myocardial ischemia. This would suggest that routine troponin monitoring is necessary in these patients, as opposed to symptom initiated troponin surveillance which would result in missing most of the patients who sustain myocardial injury. Despite being clinically silent, myocardial injury proved to be an independent predictor of both 1-year mortality and MACE. The incidence of 1-year mortality in the myocardial injury group was at least $25 \%$ in the lowest threshold and surpassed $40 \%$ in the highest. Similar findings were shown for 1-year MACE outcomes. These findings may partly explain why despite all the technical improvements in revascularization techniques, the mortality rate after revascularization has remained at a high level for the past several decades, [39] as we have not been able to adequately identify patients at risk without postoperative troponin surveillance.
To our knowledge, this is the first study evaluating myocardial injury after endovascular treatment in CLI patients with almost $100 \%$ complete follow-up.

Our study has limitations. Statistical association of myocardial injury with final outcomes was based on a priori specified thresholds. It is possible that our thresholds are not optimal, and should be re-evaluated in other studies. Troponins were measured after the treatment only at two time points with the possibility that we missed elevated troponins on the following days after EVT. Our approach to troponin surveillance was, however, pragmatic, as most of the patients are discharged on the day after endovascular revascularization, and further measurements would not be available. Finally, troponin elevation after endovascular revascularization might have resulted from etiologies other than ischemia. Further studies evaluating the mechanism of myocardial injury after endovascular revascularization are needed.

\section{Conclusions}

Preoperative troponins and NT-proBNP are commonly elevated in patients with CLI undergoing endovascular procedures suggesting high risk of cardiac diseases. One in four revascularization patients experienced myocardial injury after endovascular revascularization with $>25 \%$ mortality within the subsequent year suggesting that myocardial injury is a trigger for future outcomes. The majority of patients who experienced myocardial injury after revascularization did not present with clinical signs or ECG changes indicative of myocardial ischemia, and would probably go unnoticed without troponin screening.

Acknowledgements The authors thank Sylwia Bartyzel and Agnieszka Wolny for their help in recruiting patients, and Łukasz Derylo for statistical support.

Open Access This article is distributed under the terms of the Creative Commons Attribution 4.0 International License (http://creativecommons.org/licenses/by/4.0/), which permits unrestricted use, distribution, and reproduction in any medium, provided you give appropriate credit to the original author(s) and the source, provide a link to the Creative Commons license, and indicate if changes were made.

\section{References}

1. Fowkes FG, Rudan D, Rudan I, Aboyans V, Denenberg JO, McDermott MM, Norman PE, Sampson UK, Williams LJ, Mensah GA, Criqui MH (2013) Comparison of global estimates of prevalence and risk factors for peripheral artery disease in 2000 and 2010: a systematic review and analysis. Lancet 382(9901):13291340. https://doi.org/10.1016/S0140-6736(13)61249-0 
2. Nehler MR, Duval S, Diao L, Annex BH, Hiatt WR, Rogers K, Zakharyan A, Hirsch AT (2014) Epidemiology of peripheral arterial disease and critical limb ischemia in an insured national population. J Vasc Surg 60(3):686-695. https://doi.org/10.1016/j. jvs.2014.03.290 (e682)

3. Kullo IJ, Rooke TW (2016) Clinical practice. Peripheral artery disease. N Engl J Med 374(9):861-871. https://doi.org/10.1056/ NEJMcp1507631

4. Lau JF, Weinberg MD, Olin JW (2011) Peripheral artery disease. Part 1: clinical evaluation and noninvasive diagnosis. Nat Rev Cardiol 8(7):405-418. https://doi.org/10.1038/nrcardio.2011.66

5. Hirsch AT, Criqui MH, Treat-Jacobson D, Regensteiner JG, Creager MA, Olin JW, Krook SH, Hunninghake DB, Comerota AJ, Walsh ME, McDermott MM, Hiatt WR (2001) Peripheral arterial disease detection, awareness, and treatment in primary care. JAMA 286(11):1317-1324

6. European Stroke O, Tendera M, Aboyans V, Bartelink ML, Baumgartner I, Clement D, Collet JP, Cremonesi A, De Carlo M, Erbel R, Fowkes FG, Heras M, Kownator S, Minar E, Ostergren J, Poldermans D, Riambau V, Roffi M, Rother J, Sievert H, van Sambeek M, Zeller T, Guidelines ESCCfP (2011) ESC Guidelines on the diagnosis and treatment of peripheral artery diseases: document covering atherosclerotic disease of extracranial carotid and vertebral, mesenteric, renal, upper and lower extremity arteries: the task force on the diagnosis and treatment of peripheral artery diseases of the European Society of Cardiology (ESC). Eur Heart J 32(22):2851-2906. https://doi.org/10.1093/eurheartj/ehr211

7. Shishehbor MH, Jaff MR (2016) Percutaneous therapies for peripheral artery disease. Circulation 134(24):2008-2027. https:// doi.org/10.1161/CIRCULATIONAHA.116.022546

8. Gerhard-Herman MD, Gornik HL, Barrett C, Barshes NR, Corriere MA, Drachman DE, Fleisher LA, Fowkes FG, Hamburg NM, Kinlay S, Lookstein R, Misra S, Mureebe L, Olin JW, Patel RA, Regensteiner JG, Schanzer A, Shishehbor MH, Stewart KJ, Treat-Jacobson D, Walsh ME (2017) 2016 AHA/ACC guideline on the management of patients with lower extremity peripheral artery disease: a report of the American College of Cardiology/ Amercan Heart Association Task Force on clinical practice guidelines. Circulation 135(12):e726-e779. https://doi.org/10.1161/ CIR.0000000000000471

9. Giannitsis E, Spanuth E, Horsch A, Kleber ME, Koch W, Grammer TB, Koenig W, Marz W (2013) High-sensitivity cardiac troponin $\mathrm{T}$ and $\mathrm{N}$-terminal pro-B-type natriuretic peptide predict mortality in stable coronary artery disease: results from the Ludwigshafen risk and cardiovascular health (LURIC) study. Clin Chem Lab Med 51(10):2019-2028. https://doi.org/10.1515/ cclm-2012-0786

10. Gerhard-Herman MD, Gornik HL, Barrett C, Barshes NR, Corriere MA, Drachman DE, Fleisher LA, Fowkes FG, Hamburg NM, Kinlay S, Lookstein R, Misra S, Mureebe L, Olin JW, Patel RA, Regensteiner JG Schanzer A, Shishehbor MH, Stewart KJ, Treat-Jacobson D, Walsh ME (2016) 2016 AHA/ACC guideline on the management of patients with lower extremity peripheral artery disease: executive summary: a report of the American College of Cardiology/American Heart Association Task Force on clinical practice guidelines. Circulation. https://doi.org/10.1161/ CIR.0000000000000470

11. Varu VN, Hogg ME, Kibbe MR (2010) Critical limb ischemia. J Vasc Surg 51(1):230-241. https://doi.org/10.1016/j. jvs.2009.08.073

12. Norgren L, Hiatt WR, Dormandy JA, Nehler MR, Harris KA, Fowkes FG, Group TIW (2007) Inter-society consensus for the management of peripheral arterial disease (TASC II). J Vasc Surg 45(Suppl S):S5-S67. https://doi.org/10.1016/j.jvs.2006.12.037

13. Soga Y, Iida O, Takahara M, Hirano K, Suzuki K, Kawasaki D, Miyashita Y, Tsuchiya T (2014) Two-year life expectancy in patients with critical limb ischemia. JACC Cardiovasc Interv 7(12):1444-1449. https://doi.org/10.1016/j.jcin.2014.06.018

14. Bradbury AW, Adam DJ, Bell J, Forbes JF, Fowkes FG, Gillespie I, Ruckley CV, Raab GM, Participants BT (2010) Bypass versus angioplasty in severe ischaemia of the leg (BASIL) trial: a survival prediction model to facilitate clinical decision making. J Vasc Surg 51(5 Suppl):52S-68S. https://doi.org/10.1016/j. jvs.2010.01.073

15. Vascular Events In Noncardiac Surgery Patients Cohort Evaluation Study I, Devereaux PJ, Chan MT, Alonso-Coello P, Walsh M, Berwanger O, Villar JC, Wang CY, Garutti RI, Jacka MJ, Sigamani A, Srinathan S, Biccard BM, Chow CK, Abraham V, Tiboni M, Pettit S, Szczeklik W, Lurati Buse G, Botto F, Guyatt G, Heels-Ansdell D, Sessler DI, Thorlund K, Garg AX, Mrkobrada M, Thomas S, Rodseth RN, Pearse RM, Thabane L, McQueen MJ, VanHelder T, Bhandari M, Bosch J, Kurz A, Polanczyk C, Malaga G, Nagele P, Le Manach Y, Leuwer M, Yusuf S (2012) Association between postoperative troponin levels and 30-day mortality among patients undergoing noncardiac surgery. JAMA 307(21):2295-2304. https://doi.org/10.1001/jama.2012.5502

16. van Waes JA, Nathoe HM, de Graaff JC, Kemperman H, de Borst GJ, Peelen LM, van Klei WA, Cardiac Health After Surgery I (2013) Myocardial injury after noncardiac surgery and its association with short-term mortality. Circulation 127 (23):2264-2271. https://doi.org/10.1161/CIRCULATIONAHA.113.002128

17. Levy M, Heels-Ansdell D, Hiralal R, Bhandari M, Guyatt G, Yusuf S, Cook D, Villar JC, McQueen M McFalls E, Filipovic M, Schunemann H, Sear J, Foex P, Lim W, Landesberg G, Godet G, Poldermans D, Bursi F, Kertai MD, Bhatnagar N, Devereaux PJ (2011) Prognostic value of troponin and creatine kinase muscle and brain isoenzyme measurement after noncardiac surgery: a systematic review and meta-analysis. Anesthesiology 114(4):796806. https://doi.org/10.1097/ALN.0b013e31820ad503

18. Writing Committee for the Vision Study, Devereaux PJ, Biccard BM, Sigamani A, Xavier D, Chan MTV, Srinathan SK, Walsh M, Abraham V, Pearse R, Wang CY, Sessler DI, Kurz A, Szczeklik W, Berwanger O, Villar JC, Malaga G, Garg AX, Chow CK, Ackland G, Patel A, Borges FK, Belley-Cote EP, Duceppe E, Spence J, Tandon, Williams C, Sapsford RJ, Polanczyk CA, Tiboni M, Alonso-Coello P, Faruqui A, Heels-Ansdell D, Lamy A, Whitlock R, LeManach Y, Roshanov PS, McGillion M, Kavsak P, McQueen MJ, Thabane L, Rodseth RN, Buse GAL, Bhandari M, Garutti I, Jacka MJ, Schunemann HJ, Cortes OL, Coriat P, Dvirnik N, Botto F, Pettit S, Jaffe AS, Guyatt GH (2017) Association of postoperative high-sensitivity troponin levels with myocardial injury and 30-day mortality among patients undergoing noncardiac surgery. JAMA 317(16):1642-1651. https://doi.org/10.1001/ jama.2017.4360

19. Kim WK, Liebetrau C, van Linden A, Blumenstein J, Gaede L, Hamm CW, Walther T, Mollmann (2016) Myocardial injury associated with transcatheter aortic valve implantation (TAVI). Clin Res Cardiol 105(5):379-387. https://doi.org/10.1007/ s00392-015-0949-6

20. Botto F, Alonso-Coello P, Chan MTV, Villar JC, Xavier D, Srinathan S, Guyatt G, Cruz P, Graham M, Wang CY, Berwanger O, Pearse RM, Biccard BM, Abraham V, Malaga G, Hillis GS, Rodseth RN, Cook D, Polanczyk CA, Szczeklik W, Sessler DI, Sheth T, Ackland GL, Leuwer M, Garg AX, LeManach Y, Pettit S, Heels-Ansdell D, LuratiBuse G, Walsh M, Sapsford R, Schunemann HJ, Kurz A, Thomas S, Mrkobrada M, Thabane L, Gerstein H, Paniagua P, Nagele P, Raina P, Yusuf S, Devereaux PJ (2014) Myocardial injury after noncardiac surgery: a large, international, prospective cohort study establishing diagnostic criteria, characteristics, predictors, and 30-day outcomes. Anesthesiology 120(3):564-578. https://doi.org/10.1097/ ALN.0000000000000113 
21. Thygesen K, Alpert JS, Jaffe AS, Simoons ML, Chaitman BR, White HD, Joint ESCAAHAWHFTFfUDoMI Authors/TaskF Members C, Thygesen K, Alpert JS, White HD, Biomarker S, Jaffe AS, Katus HA, Apple FS, Lindahl B, Morrow DA, Subcommittee ECG, Chaitman BR, Clemmensen PM, Johanson P, Hod H, Imaging S, Underwood R, Bax JJ, Bonow JJ, Pinto F, Gibbons RJ, Classification S, Fox KA, Atar D, Newby LK, Galvani M, Hamm CW, Intervention S, Uretsky BF, Steg PG, Wijns W, Bassand JP, Menasche P, Ravkilde J, Trials Registries S, Ohman EM, Antman EM, Wallentin LC, Armstrong PW, Simoons ML, Trials egistries S, Januzzi JL, Nieminen MS, Gheorghiade M, Filippatos G, Trials Registries S, Luepker RV, Fortmann SP, Rosamond WD, Levy D, Wood D, Trials Registries S, Smith SC, Hu D, Lopez-Sendon JL, Robertson RM, Weaver D, Tendera M, Bove AA, Parkhomenko AN, Vasilieva EJ, Mendis S, Guidelines ESCCfP, Bax JJ, Baumgartner H, Ceconi C, Dean V, Deaton C, Fagard R, Funck-Brentano C, Hasdai D, Hoes A, Kirchhof P, Knuuti J, Kolh P, McDonagh T, Moulin C, Popescu BA, Reiner Z, Sechtem U, Sirnes PA, Tendera M, Torbicki A, Vahanian A, Windecker S, Document R, Morais J, Aguiar C, Almahmeed W, Arnar DO, Barili F, Bloch $\mathrm{KD}$, Bolger AF, Botker HE, Bozkurt B, Bugiardini R, Cannon C, de Lemos J, Eberli FR, Escobar E, Hlatky M, James S, Kern KB, Moliterno DJ, Mueller C, Neskovic AN, Pieske BM, Schulman SP, Storey RF, Taubert KA, Vranckx P, Wagner DR (2012) Third universal definition of myocardial infarction. J Am Coll Cardiol 60(16):1581-1598. https://doi.org/10.1016/j.jacc.2012.08.001

22. Biccard BM, Scott DJA, Chan MTV, Archbold A, Wang CY, Sigamani A, Urrutia G, Cruz P, Srinathan SK, Szalay D, Harlock J, Tittley JG, Rapanos T, Elias F, Jacka MJ, Malaga G, Abraham V, Berwanger O, Montes FR, Heels-Ansdell DM, Hutcherson MT, Chow CK, Polanczyk CA, Szczeklik W, Ackland GL, Dubois L, Sapsford RJ, Williams C, Cortes OL, Le Mananch Y, Devereaux PJ (2017) Myocardial injury after noncardiac surgery (MINS) in Vascular surgical patients: a prospective observational cohort study. Ann Surg. https://doi.org/10.1097/SLA.0000000000002290

23. Devereaux PJ, Goldman L, Cook DJ, Gilbert K, Leslie K, Guyatt GH (2005) Perioperative cardiac events in patients undergoing noncardiac surgery: a review of the magnitude of the problem, the pathophysiology of the events and methods to estimate and communicate risk. CMAJ 173(6):627-634. https://doi.org/10.1503/ cmaj.050011

24. Gaggin HK, Liu Y, Lyass A, van Kimmenade RR, Motiwala SR, Kelly NP, Mallick A, Gandhi PU, Ibrahim NE, Simon ML, Bhardwaj A, Belcher AM, Harisiades JE, Massaro JM, D'Agostino RB, $\mathrm{S}$, anuzzi JL, Jr (2017) Incident type 2 myocardial infarction in a cohort of patients undergoing coronary or peripheral arterial angiography. Circulation 135(2):116-127. https://doi.org/10.1161/ CIRCULATIONAHA.116.023052

25. Giannitsis E, Kurz K, Hallermayer K, Jarausch J, Jaffe AS, Katus HA (2010) Analytical validation of a high-sensitivity cardiac troponin T assay. Clin Chem 56(2):254-261. https://doi.org/10.1373/ clinchem.2009.132654

26. Apple FS, Pearce LA, Smith SW, Kaczmarek JM, Murakami MM (2009) Role of monitoring changes in sensitive cardiac troponin I assay results for early diagnosis of myocardial infarction and prediction of risk of adverse events. Clin Chem 55(5):930-937. https://doi.org/10.1373/clinchem.2008.114728

27. Hildebrandt P, Collinson PO, Doughty RN, Fuat A, Gaze DC, Gustafsson F, Januzzi J, Rosenberg J, Senior R, Richards M (2010) Age-dependent values of N-terminal pro-B-type natriuretic peptide are superior to a single cut-point for ruling out suspected systolic dysfunction in primary care. Eur Heart J 31(15):18811889. https://doi.org/10.1093/eurheartj/ehq163

28. Bhatt DL, Steg PG, Ohman EM, Hirsch AT, Ikeda Y, Mas JL, Goto S, Liau CS, Richard AJ, Rother J, Wilson PW, Investigators
RR (2006) International prevalence, recognition, and treatment of cardiovascular risk factors in outpatients with atherothrombosis. JAMA 295(2):180-189. https://doi.org/10.1001/jama.295.2.180

29. Chen DC, Singh GD, Armstrong EJ, Waldo SW, Laird JR, Amsterdam EA (2017) Long-term comparative outcomes of patients with peripheral artery disease with and without concomitant coronary artery disease. Am J Cardiol 119(8):1146-1152. https://doi. org/10.1016/j.amjcard.2016.12.023

30. Hertzer NR, Beven EG, Young JR, O'Hara PJ, Ruschhaupt WF, 3rd, Graor RA, Dewolfe VG, Maljovec LC (1984) Coronary artery disease in peripheral vascular patients. A classification of 1000 coronary angiograms and results of surgical management. Ann Surg 199 (2):223-233

31. de Lemos JA, Morrow DA, Bentley JH, Omland T, Sabatine MS, McCabe CH, Hall C, Cannon CP, Braunwald E (2001) The prognostic value of B-type natriuretic peptide in patients with acute coronary syndromes. N Engl J Med 345(14):1014-1021. https:// doi.org/10.1056/NEJMoa011053

32. Doust JA, Pietrzak E, Dobson A, Glasziou P (2005) How well does B-type natriuretic peptide predict death and cardiac events in patients with heart failure: systematic review. BMJ 330(7492):625. https://doi.org/10.1136/bmj.330.7492.625

33. Vasan RS (2006) Biomarkers of cardiovascular disease: molecular basis and practical considerations. Circulation 113(19):23352362. https://doi.org/10.1161/CIRCULATIONAHA.104.482570

34. Writing Committee M, Yancy CW, Jessup M, Bozkurt B, Butler J, Casey DE Jr, Drazner MH, Fonarow GC, Geraci SA, Horwich T, Januzzi JL, Johnson MR, Kasper EK, Levy WC, Masoudi FA, McBride PE, McMurray JJ, Mitchell JE, Peterson PN, Riegel B, Sam F, Stevenson LW, Tang WH, Tsai EJ, Wilkoff BL, American College of Cardiology Foundation/American Heart Association Task Force on Practice G (2013) 2013 ACCF/AHA guideline for the management of heart failure: a report of the American College of Cardiology Foundation/American Heart Association Task Force on practice guidelines. Circulation 128(16):e240-e327. https://doi.org/10.1161/CIR.0b013e31829e8776

35. Pohlhammer J, Kronenberg F, Rantner B, Stadler M, Peric S, Hammerer-Lercher A, Klein-Weigel P, Fraedrich G, Kollerits B (2014) High-sensitivity cardiac troponin $\mathrm{T}$ in patients with intermittent claudication and its relation with cardiovascular events and all-cause mortality-the CAVASIC study. Atherosclerosis 237(2):711-717. https://doi.org/10.1016/j. atherosclerosis.2014.10.097

36. Spark JI, Sarveswaran J, Blest N, Charalabidis P, Asthana S (2010) An elevated neutrophil-lymphocyte ratio independently predicts mortality in chronic critical limb ischemia. J Vasc Surg 52(3):632-636. https://doi.org/10.1016/j.jvs.2010.03.067

37. Hikita H, Shigeta T, Kimura S, Takahashi A, Isobe M (2015) Coronary artery disease severity and cardiovascular biomarkers in patients with peripheral artery disease. Int J Angiol 24(4):278282. https://doi.org/10.1055/s-0035-1555133

38. Kumakura H, Kanai H, Araki Y, Hojo Y, Kasama S, Sumino H, Iwasaki T, Takayama Y, Ichikawa S, Fujita K, Nakashima K, Minami K (2013) Differences in brain natriuretic peptide and other factors between Japanese peripheral arterial disease patients with critical limb ischemia and intermittent claudication. J Atheroscler Thromb 20(11):798-806

39. Reinecke H, Unrath M, Freisinger E, Bunzemeier H, Meyborg M, Luders F, Gebauer K, Roeder N, Berger K, Malyar NM (2015) Peripheral arterial disease and critical limb ischaemia: still poor outcomes and lack of guideline adherence. Eur Heart J 36(15):932-938. https://doi.org/10.1093/eurheartj/ehv006 